\title{
STUDIES ON THE ALLERGY-LIKE FOOD POISONING ASSOCIATED WITH PUTREFACTION OF MARINE PRODUCTS \\ IV. EFFECT OF TRIMETHYLAMINE AND TRIMETHYLAMINE OXIDE ADDED TO HISTAMINE OF "SAURINE" UPON THEIR OWN PHYSIOLOGICAL ACTION
}

\author{
TOSHIHARU KAWABATA*, KIMISHIGE ISHIZAKA** AND \\ TOSHIYUKI MIURA*
}

The National Institute of Health, Tokyo

(Received: December 28th, 1955)

\section{INTRODUCTION}

Miyaki et al ${ }^{(1)}$ pointed out that the main causative agents of some allergylike food poisoning might be unusual amount of histamine and other cooperative factors contained in the incriminated material. They presumed that such biogenic amines as agmatine, phosphorylcholine or methylguanidine would play synergistic action to histamine in decreasing its lethal dose for mice. Hayashi(2), using uterus of guinea pigs, in his subsequent experiment, described the action of trimethylamine (TMA) or trimethylamine oxide (TMAO) to enhance the action of histamine, and he also reported a similar observation by means of blood pressure method using cats when TMA, TMAO or phosphorylcholine was added to histamine.

The present paper deals with the effect of TMA or TMAO added to "saurine" or histamine upon their respective physiological action tested on the contractility of intestine or uterus of guinea pigs, shock symptoms in guinea pigs, skin reaction in rabbits and lethal dose for mice $\left(\mathrm{LD}_{50}\right)$.

\section{EXPERIMENTALS}

Exp. 1. Tests on the Contractility of Intestine and Uterus of Guinea Pigs

a. Method i) "Saurine" solution was prepared by the same procedure as described in our previous paper, III. Four tenths cc of "saurine" was found corresponding to $2 \gamma$ of histamine in its action to contract intestine of guinea pigs by Magnus' method.

ii) The following four test-solutions were used.

\begin{tabular}{l|c}
\hline & Concent. of original solution \\
\hline TMA (Wako Pure Chemicals Co.) & $10^{-1} \mathrm{M}$ \\
TMAO &, \\
Histamine (Merck Co.) &, \\
Histidine (Takeda Chem. Co.)
\end{tabular}

* Department of Food Control

* Department of Serology 
iii) Contraction test using uterus or intestine of guinea pigs:

Contraction of uterus or intestine was determined by Magnus' method. The technique adopted by Hayashi(2) was as follows: Using uterus of guinea pigs, threshold value, the maximum concentration of no visible contraction, was deter-

Fig. 1. The effect of TMA or TMAO added to histamine or "saurine" tested on the contraction of uterus of guinea pigs

〔A]
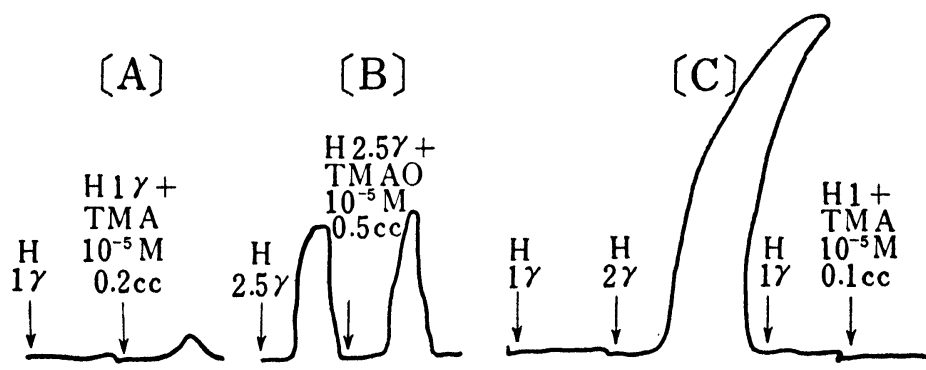

(D)

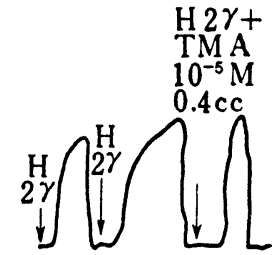

[E]
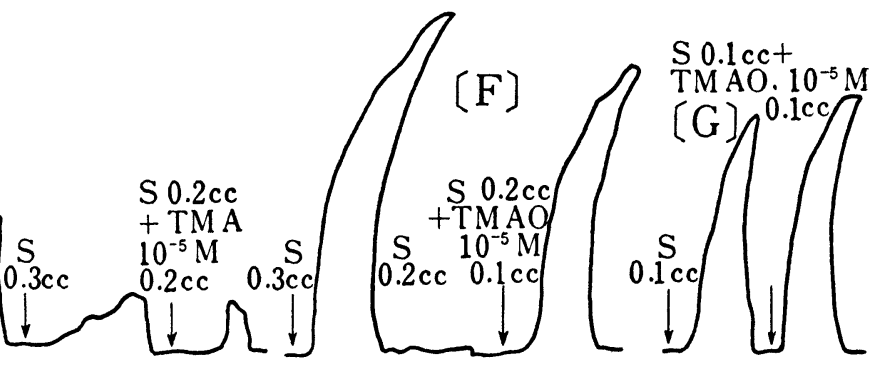

$\mathrm{H}$ : histamine

S: "saurine"

Table 1. Summarized results on the effect of TMA or TMAO added to histamine or "saurine" shown in those kymogram of Fig. 1

\begin{tabular}{|c|c|c|c|c|}
\hline Kymogram & Test solution & Synergism & $\begin{array}{l}\text { Rate of } \\
\text { increase }\end{array}$ & Method \\
\hline A & $\mathrm{H}, 1 \gamma+\mathrm{TMAO} 10^{-5 \mathrm{M}, 0.2 \mathrm{cc}}$ & + & & I \\
\hline B & $\mathrm{H}, 2.5 \gamma+\mathrm{TMAO} 10^{-5} \mathrm{M}, 0.5 \mathrm{cc}$ & + & $<10 \%$ & II \\
\hline $\mathrm{C}$ & $\mathrm{H}, 1 \gamma+\mathrm{TMA} 10^{-5} \mathrm{M}, 0.1 \mathrm{cc}$ & - & & $\mathrm{I}$ \\
\hline D & $\mathrm{H}, 2 \gamma+\mathrm{TMA} 10^{-5} \mathrm{M}, 0.4 \mathrm{cc}$ & - & $0 \%$ & II \\
\hline $\mathrm{E}$ & $\mathrm{S}, 0.2 \mathrm{cc}+\mathrm{TMA} 10^{-5} \mathrm{M}, 0.2 \mathrm{cc}$ & + & & I \\
\hline $\mathrm{F}$ & $\mathrm{S}, 0.3 \mathrm{cc}+\mathrm{TMAO} 10^{-5} \mathrm{M}, 0.2 \mathrm{cc}$ & + & & I \\
\hline G & $\mathrm{S}, 0.1 \mathrm{cc}+\mathrm{TMAO} 10^{-5 \mathrm{M}, 0.1 \mathrm{cc}}$ & + & $<5 \%$ & II \\
\hline
\end{tabular}

Note: H: histamine, S: "saurine"

Method I: qualitative method, II: quantitative

mined prior to the examination. Then, after adding appropriate concentration of other kind of amine to the threshold value of histamine, change in contraction of uterus was observed. In this respect, this procedure might be regarded as a qualitative method. In this paper, a quantitative method using intestine as well as uterus were employed. The method was detailed in our paper $I^{(3)}$. 
b. Results i) Synergistic action judged by the results using uterus:

As shown in Fig. 1 and Table 1, sometimes synergistic action of TMA or TMAO added to either histamine or "saurine" was observed to some extent (see A, B, E, F and G in Fig. 1), and sometimes no action was recorded in the same experiment (see $\mathrm{C}$ and $\mathrm{D}$ in Fig. 1). However, even when positive synergistic action was observed, the rate of increase in the action of histamine or "saurine" was less than $10 \%$ (which seemed to be within the range of error). Sometimes, strong spontaneous contraction occurred during experiment. These irregular results might have been due mainly to the nature of contraction of uterus.

ii) Synergism judging from the contractility of intestine

$$
\text { -quantitative method- }
$$

$T M A+H$ istamine

No appreciable contraction of intestine was observed with $1 \mathrm{cc}$ of $10^{-2} \mathrm{M}$ TMA only, but slight action was recorded with $0.3 \mathrm{cc}$ of $10^{-1} \mathrm{M}$. As shown in Table 2, no significant synergism was detected with TMA plus histamine, except-

Table 2. Histamine added to TMA

\begin{tabular}{|c|c|c|c|}
\hline Histamine & TMA & $\begin{array}{c}\text { Contraction of intestine } \\
\text { (shown in equivalent histamine) }\end{array}$ & Synergism \\
\hline- & $10^{-2} \mathrm{M}, 1 \mathrm{cc}$ & - & \\
\hline- & $10^{-1} \mathrm{M}, 0.3$, & weak & \\
\hline $2 \gamma$ & $10^{-8} \mathrm{M}, 0.5$, & $2 \gamma$ & - \\
\hline ” & 10-7M, , & $2 \gamma \sim 2.1 \gamma$ & - \\
\hline , & $10^{-6} \mathrm{M}, \quad$, & $2 \gamma$ & - \\
\hline ” & $10^{-5} \mathrm{M}, \quad$, & " & - \\
\hline ” & $10^{-4} \mathrm{M}, \quad$, & " & - \\
\hline ” & 10-3M, , & , & - \\
\hline
\end{tabular}

The effect of pretreatment of intestine with TMA

\begin{tabular}{c|c|c|c}
\hline TMA & Histamine & $\begin{array}{c}\text { Contraction of intestine } \\
\text { (shown in equivalent histamine) }\end{array}$ & Synergism \\
\hline $10-7 \mathrm{M}, 0.5 c c$ & $1.5 \gamma$ & $1.5 \gamma$ & - \\
$10-6 \mathrm{M},,$, & $2,$, & $2, \%$ & - \\
$10-5 \mathrm{M},$, & 2, & 2, & -
\end{tabular}

ing a case with $0.5 \mathrm{cc}$ of $10^{-7} \mathrm{M}$. In this case, however, the rate of increase was within $5 \%$ which might be within the range of error. Increase in the rate of contraction of the intestine could hardly be detectable when the intestine had been pretreated with TMA, allowed to stand for 1 minute, and then histamine was added. 
Histidine+Histamine

Histidine has no activity to contract intestine of guinea pigs ( $0.5 \mathrm{cc}$ of $1^{-1} \mathrm{M}$ solution). Addition of histidine to histamine resulted in no detectable change to decrease or increase in its contractility of intestine (see Table 3).

Table 3. Histidine added to histamine

\begin{tabular}{|c|c|c|c|}
\hline Histamine & Histidine & $\begin{array}{c}\text { Contraction of intestine } \\
\text { (shown in equivalent histamine) }\end{array}$ & Synergism \\
\hline- & $10^{-1} \mathrm{M}, 0.5 \mathrm{cc}$ & - & \\
\hline $2 \gamma$ & $10-7 \mathrm{M}, 1 \mathrm{cc}$ & $2 \gamma$ & - \\
\hline " & $10^{-6} \mathrm{M}, \quad$, & ” & - \\
\hline , & $10^{-5} \mathrm{M}$, & , & - \\
\hline , & $10^{-4} \mathrm{M}, \quad$, & , & - \\
\hline $1 \gamma$ & $10^{-7} \mathrm{M}$, & $1 \gamma$ & - \\
\hline 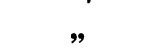 & $10^{-6} \mathrm{M}$, & , & - \\
\hline " & $10^{-5} \mathrm{M}, \quad$, & ” & - \\
\hline
\end{tabular}

\section{$T M A O+H i s t a m i n e$}

One half cc of $10^{-1} \mathrm{M}$ TMAO did not affect intestine to any measurable extent. Results with the mixture consisted of TMAO and histamine are shown in the upper column of Table 4, which indicates negative synergism. Using

Table 4. TMAO added to histamine

\begin{tabular}{|c|c|c|c|}
\hline TMAO & Histamine & $\begin{array}{l}\text { Contraction of intestine } \\
\text { (shown in equivalent histamine) }\end{array}$ & Synergism \\
\hline $10^{-1} \mathrm{M}, 0.5 \mathrm{cc}$ & - & - & \\
\hline $10^{-5} \mathrm{M}, 0.7 \mathrm{cc}$ & $1 \gamma$ & $1 \gamma$ & - \\
\hline , , 0.1cc & $2 \gamma$ & $2 \gamma$ & - \\
\hline $10^{-8} \mathrm{M}, 1$ cc & $1 \gamma$ & $1 \gamma$ & - \\
\hline$, \quad, 0.5 \mathrm{cc}$ & " & " & - \\
\hline , , , & $2 \gamma$ & $2 \gamma$ & - \\
\hline \multicolumn{2}{|c|}{ Pretreatment with TMAO } & & \\
\hline $10^{-5} \mathrm{M}, 0.3 \mathrm{cc}$ & 1 min. after $2 \gamma$ & $2 \gamma$ & - \\
\hline $10^{-8} \mathrm{M}, 0.5 \mathrm{cc}$ & " & , & - \\
\hline
\end{tabular}

uterus, Hayashi(2) pointed out that a synergistic effect of TMAO to histamine was detectable at the concentration of $10^{-5} \mathrm{M}$, whereas it acted either synergistic or inhibitory when the addition was made in different sequences or in different amounts to histamine. However, quantitative method using intestine carried out by the present authors disclosed that no significant increase or decrease was observed in the contractility of histamine even when the intestine was pretreated with TMAO. 
$T M A+" S a u r i n e "$

As shown in Table 5, the contractility of "saurine" was not enhanced by the addition of TMA, agreeing with the results with TMA plus histamine.

Table 5. TMA added to "saurine"

\begin{tabular}{|c|c|c|c|}
\hline TMA & "saurine" & $\begin{array}{c}\text { Contraction of intestine } \\
\text { (shown in equivalent histamine) }\end{array}$ & Synergism \\
\hline $10^{-2} \mathrm{M}, 0.9 \mathrm{cc}$ & $0.3 \mathrm{cc}$ & $1.5 \gamma$ & - \\
\hline $10^{-3} \mathrm{M}$ & $川$ & 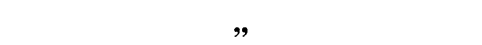 & - \\
\hline $10^{-4} \mathrm{M}$, & , & , & - \\
\hline $10^{-5} \mathrm{M}$, & , & , & - \\
\hline $10^{-6} \mathrm{M}$, & ” & , & - \\
\hline $10^{-7} \mathrm{M}$, & $"$ & ” & - \\
\hline
\end{tabular}

TMAO+"Saurine"

No synergistic effect was detected by the addition of TMAO to "saurine" on its contractility of intestine. Results obtained are shown in Table 6 .

Table 6. TMAO added to "saurine"

\begin{tabular}{c|c|c|c}
\hline TMAO & saurine & $\begin{array}{c}\text { Contraction of intestine } \\
\text { (shown in equivalent histamine) }\end{array}$ & Synergism \\
\hline $10-2 \mathrm{M}, 0.9 \mathrm{cc}$ & $0.4 \mathrm{cc}$ & $2 \gamma$ & - \\
$10-3 \mathrm{M}, "$ &, &, & - \\
$10-4 \mathrm{M}, "$ &, &, & - \\
$10-5 \mathrm{M}, "$ &, &, & - \\
$10-6 \mathrm{M},, "$ &, &, & - \\
$10-7 \mathrm{M},$, &, &, &
\end{tabular}

Four tenths cc of "saurine" is equivalent to $2 \gamma$ of histamine

\section{Histidine+"Saurine"}

Addition of histidine to "saurine" resulted in negative synergism in its contractility of intestine (see Table 7).

Table 7. Histidine added to saurine

\begin{tabular}{|c|c|c|c|}
\hline Histidine & saurine & $\begin{array}{c}\text { Contraction of intestine } \\
\text { (shown in equivalent histamine) }\end{array}$ & Synergism \\
\hline $10^{-1} \mathrm{M}, 0.5 \mathrm{cc}$ & & - & \\
\hline $10^{-3} \mathrm{M}, 0.9 \mathrm{cc}$ & $0.2 \mathrm{cc}$ & $1 \gamma$ & - \\
\hline $10^{-4} \mathrm{M}, \quad$, & " & " & - \\
\hline $10^{-5} \mathrm{M}$, & " & " & - \\
\hline $10^{-6} \mathrm{M}$, & " & 川 & - \\
\hline $10-7 \mathrm{M}$, & , & ", & - \\
\hline
\end{tabular}


Histamine+ "Saurine"

Additive effect between histamine and "saurine" has been reported in our paper III; re-examination on the mixture of both solutions rendered our finding more valid, in which the rate of contraction of the mixture of both solutions agreed with that of total of the rate of contraction of each solution. These results seem to prove the presence of an additive effect and the absence of synergism between them.

Table 8. Effect observed between histamine and "saurine"

\begin{tabular}{c|c|c|c}
\hline Histamine & Saurine & $\begin{array}{c}\text { Contraction of intestine } \\
\text { (shown in equivalent histamine) }\end{array}$ & Effect \\
\hline $1 \gamma$ & $0.4 \mathrm{cc}$ & $2 \gamma$ & additive \\
1, & $0.2 \mathrm{cc}$ & 1.5 &, \\
1, & $0.2 \mathrm{cc}$ &, &,
\end{tabular}

Four tenths cc of "saurine" is equivalent to $1 \gamma$ of histamine

Exp. 2. Effect TMA or TMAO Added to Histamine or "Saurine" Tested on Shock Symptoms in Guinea Pigs

a. Method The minimum lethal dose of histamine or "saurine" by intravenous injection was determined with guinea pigs prior to the examination; then TMA or TMAO was added in various concentrations to the threshold value of

Table 9. Effect of TMA or TMAO added to histamine (shock symptoms in guinea pigs)

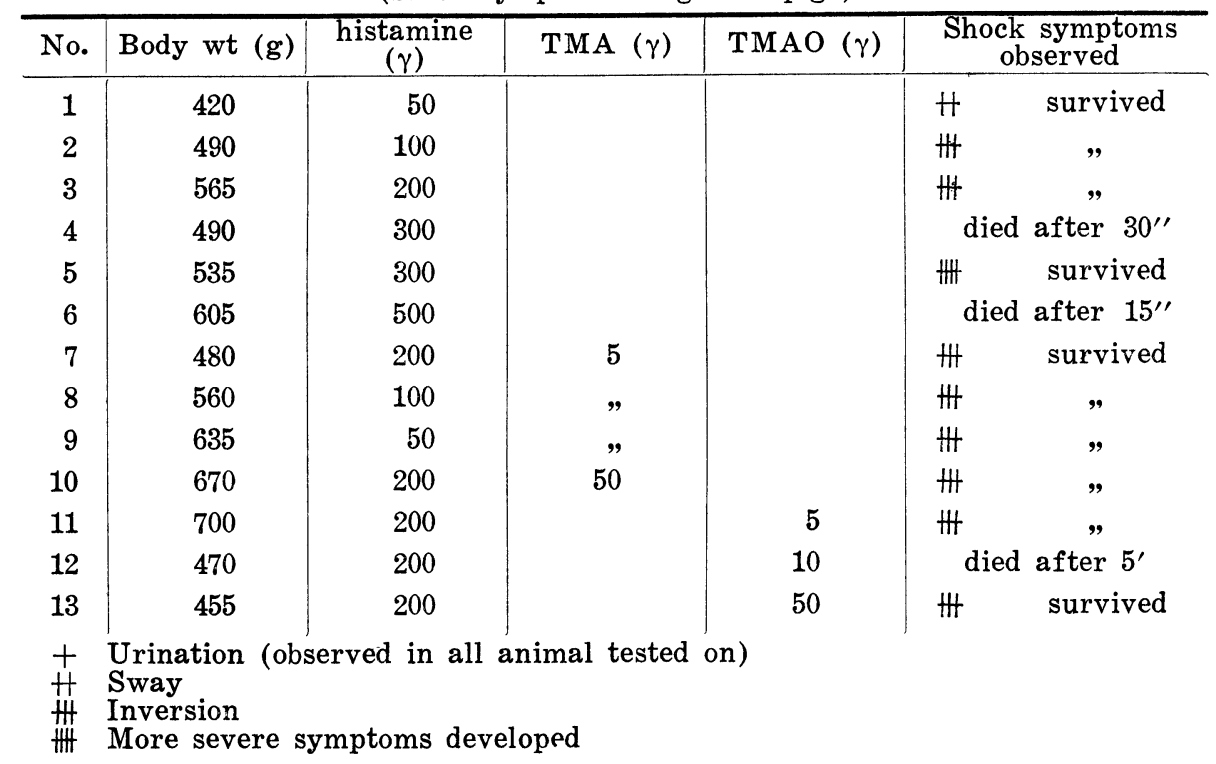


histamine or "saurine"; the latter value was expressed in equivalent histamine estimated by Magnus's method. Each test solution was simultaneously injected intravenously into guinea pigs and symptoms developed were recorded.

b. Results Results thus obtained are shown in Tables 9 and 10 . In no case, significant influence upon the lethal dose of histamine or "saurine" was observed when TMA or TMAO was added to them, excepting a case in which an injection with $200 \gamma$ of histamine containing $10 \gamma$ of TMAO brought to death. However, a typical acute death by shock with histamine is generally considered to occur 30 seconds or 1 minute after the injection. Whereas, in the case

Table 10. Effect of TMA or TMAO added "saurine" (shock symptoms in guinea pigs)

\begin{tabular}{|c|c|c|c|c|c|}
\hline No. & Body wt (g) & saurine $(\gamma)$ & TMA $(\gamma)$ & $\operatorname{TMAO}(\gamma)$ & $\begin{array}{c}\text { shock symptoms } \\
\text { observed }\end{array}$ \\
\hline 1 & 565 & 500 & & & died \\
\hline 2 & 660 & 400 & & & ” \\
\hline 3 & 565 & 200 & & & \# survived \\
\hline 4 & 550 & 200 & & - & died \\
\hline 5 & 660 & 150 & & & 冊 survived \\
\hline 6 & 635 & 200 & & 20 & died \\
\hline 7 & 540 & 150 & & 15 & survived \\
\hline 8 & 550 & 200 & 15 & & 冊 \\
\hline 9 & 690 & 150 & " & & \# \\
\hline
\end{tabular}

Dosages of "saurine" injected are shown in equivalent histamine:

卅 Inversion

M More severe symptoms developed

described above, the death happened 5 minutes after the injection and other guinea pig injected with $200 \gamma$ of histamine containing $50 \gamma$ of TMAO did survived. Therefore, the death described in the above might have been due to not the synergism but to an accident.

Exp. 3. Effect of TMA or TMAO Added to Histamine or "Saurine" Tested in Skin Reaction with Rabbits

a. Method After depilation of the backs of rabbits, $0.1 \mathrm{cc}$ of each test solution was injected intracutaneously. Original test solutions were those $500 \gamma / \mathrm{cc}$ each of histamine and "saurine" (equivalent histamine estimated by Magnus"

Table 11. Concentration of test solution and the amount of TMA or TMAO added to the test solution

\begin{tabular}{c|c|c|c|c|c|c}
\hline $\begin{array}{c}\text { Concent. of } \\
\text { histamine or } \\
\text { "saurine" }\end{array}$ & $31 \gamma$ & $15.5 \gamma$ & $7.75 \gamma$ & $3.87 \gamma$ & $1.94 \gamma$ & $0.97 \gamma$ \\
\hline $\begin{array}{c}\text { TMA or } \\
\text { TMAO }\end{array}$ & $3.1 \times 10^{-3} \mathrm{M} \mid 1.55 \times 10^{-3} \mathrm{M}$ & $7.75 \times 10^{-4} \mathrm{M}$ & $3.87 \times 10^{-4} \mathrm{M}$ & $1.94 \times 10^{-4} \mathrm{M} \mid 9.7 \times 10^{-5} \mathrm{M}$
\end{tabular}


method) and $0.5 \times 10^{-1} \mathrm{M}$ each of TMA and TMAO. The constituent parts of each test solution injected are shown in Table 11. The activity of the test solution to develop skin reaction was observed immediately after, 15 minutes and 3 hours after the injection.

b. Results As shown in Table 12, distinct redness and wale were observed with higher concentration than $7.5 \gamma / \mathrm{cc}$ of histamine and "saurine" as well, whereas, the addition of TMA or TMAO to both substances did not enhance their activity. At higher dilutions of the test solution, no significant difference in skin reaction was detected between those solution containing TMA or TMAO and those of control solution. Thus, the addition of TMA or TMAO did not increase the effect of histamine or "saurine" to develop skin reaction in rabbits.

Table 12. Effect of TMA or TMAO added to histamine or "saurine" (Skin reaction in rabbits)

\begin{tabular}{|c|c|c|c|c|c|c|c|c|c|c|}
\hline \multirow{3}{*}{$\begin{array}{c}\begin{array}{c}\text { Test } \\
\text { solution }\end{array} \\
\text { Histamine }\end{array}$} & \multirow{3}{*}{ 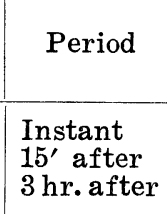 } & \multicolumn{9}{|c|}{ Concentration of histamine or "saurine" } \\
\hline & & \multicolumn{2}{|c|}{$31 \gamma$} & \multicolumn{2}{|c|}{$15.5 \gamma$} & \multicolumn{2}{|c|}{$7.75 \gamma$} & \multirow{2}{*}{$\begin{array}{c}3.87 \gamma \\
\mathrm{Q} \\
\underline{q}\end{array}$} & \multirow{2}{*}{$\begin{array}{c}1.94 \gamma \\
\mathrm{Q} \\
\underline{\mathrm{q}}\end{array}$} & \multirow{2}{*}{$\begin{array}{r}0.97 \gamma \\
\underline{Q} \\
-\end{array}$} \\
\hline & & & $\begin{array}{l}\mathrm{Q} \\
\mathrm{Q} \\
\mathrm{Q}\end{array}$ & $\begin{array}{l}\mathrm{R} \\
\mathrm{R}\end{array}$ & $\begin{array}{l}\mathbf{Q} \\
\mathbf{Q} \\
\mathbf{Q}\end{array}$ & $\begin{array}{l}\mathrm{R} \\
\mathrm{R}\end{array}$ & $\begin{array}{l}\mathrm{Q} \\
\mathrm{Q} \\
\mathrm{Q}\end{array}$ & & & \\
\hline $\begin{array}{l}\text { Histamine } \\
\text { +TMA }\end{array}$ & $\begin{array}{l}\text { Instant } \\
15^{\prime} \\
3 \mathrm{hr} .\end{array}$ & $\begin{array}{l}\mathrm{R} \\
\mathrm{R}\end{array}$ & $\begin{array}{l}\mathbf{Q} \\
\mathbf{Q} \\
\mathbf{Q}\end{array}$ & $\begin{array}{l}\mathrm{R} \\
\mathrm{R}\end{array}$ & $\begin{array}{l}\mathbf{Q} \\
\mathbf{Q} \\
\mathbf{Q}\end{array}$ & $\begin{array}{l}\mathrm{R} \\
\mathrm{R}\end{array}$ & $\begin{array}{l}\mathrm{Q} \\
\mathrm{Q} \\
\mathrm{Q}\end{array}$ & $\begin{array}{l}\mathbf{Q} \\
\mathbf{Q} \\
\mathrm{q}\end{array}$ & $\begin{array}{l}\mathrm{Q} \\
\mathbf{Q} \\
\mathbf{q}\end{array}$ & $\begin{array}{l}\mathbf{Q} \\
\mathbf{Q} \\
-\end{array}$ \\
\hline $\begin{array}{l}\text { Histamine } \\
\text { +TMAO }\end{array}$ & $\begin{array}{l}\text { Instant } \\
15^{\prime} \\
3 \mathrm{hr} .\end{array}$ & $\begin{array}{l}\mathrm{R} \\
\mathrm{R}\end{array}$ & $\begin{array}{l}\mathbf{Q} \\
\mathbf{Q} \\
\mathbf{Q}\end{array}$ & $\begin{array}{l}\mathrm{R} \\
\mathrm{R}\end{array}$ & $\begin{array}{l}\mathbf{Q} \\
\mathbf{Q} \\
\mathbf{Q}\end{array}$ & $\begin{array}{l}\mathrm{R} \\
\mathrm{R}\end{array}$ & $\begin{array}{l}\mathrm{Q} \\
\mathrm{Q} \\
\mathrm{q}\end{array}$ & $\begin{array}{l}\mathbf{Q} \\
\mathbf{Q} \\
-\end{array}$ & $\begin{array}{l}\mathbf{Q} \\
\mathbf{Q} \\
-\end{array}$ & $\begin{array}{l}\mathbf{Q} \\
\mathbf{Q} \\
-\end{array}$ \\
\hline "Saurine" & $\begin{array}{l}\text { Instant } \\
15^{\prime} \\
3 \mathrm{hr} .\end{array}$ & & $\begin{array}{l}\mathbf{Q} \\
\mathbf{Q} \\
\mathbf{Q}\end{array}$ & $\begin{array}{l}\mathrm{R} \\
\mathrm{R}\end{array}$ & $\begin{array}{l}\mathbf{Q} \\
\mathbf{Q} \\
\mathbf{Q}\end{array}$ & $\begin{array}{l}\mathrm{R} \\
\mathrm{R}\end{array}$ & $\begin{array}{l}\mathbf{Q} \\
\mathbf{Q} \\
\mathbf{Q}\end{array}$ & $\begin{array}{r} \pm Q \\
q \\
q\end{array}$ & $\begin{array}{l}Q \\
q \\
q\end{array}$ & $\frac{\mathrm{Q}}{-}$ \\
\hline $\begin{array}{l}\text { "Saurine" } \\
\text { +TMA }\end{array}$ & $\begin{array}{l}\text { Instant } \\
15^{\prime} \\
3 \mathrm{hr} \text {. }\end{array}$ & $\begin{array}{l}\mathrm{R} \\
\mathrm{R}\end{array}$ & $\begin{array}{l}\mathbf{Q} \\
\mathbf{Q} \\
\mathbf{Q}\end{array}$ & $\begin{array}{l}\mathbf{R} \\
\mathbf{R}\end{array}$ & $\begin{array}{l}\mathbf{Q} \\
\mathbf{Q} \\
\mathbf{Q}\end{array}$ & $\begin{array}{l}\mathbf{R} \\
\mathrm{R}\end{array}$ & $\begin{array}{l}\mathbf{Q} \\
\mathbf{Q} \\
\mathbf{Q}\end{array}$ & $\begin{array}{l}q \\
q \\
q\end{array}$ & $\begin{array}{l}q \\
q \\
-\end{array}$ & $\frac{q}{-}$ \\
\hline $\begin{array}{l}\text { "Saurine" } \\
\text { +TMAO }\end{array}$ & $\begin{array}{l}\text { Instant } \\
15^{\prime} \\
3 \mathrm{hr} .\end{array}$ & $\begin{array}{l}\mathrm{R} \\
\mathrm{R}\end{array}$ & $\begin{array}{l}\mathbf{Q} \\
\mathbf{Q}\end{array}$ & $\begin{array}{l}\mathbf{R} \\
\mathrm{R}\end{array}$ & $\begin{array}{l}\mathbf{Q} \\
\mathbf{Q}\end{array}$ & $\begin{array}{l}\mathrm{R} \\
\mathrm{R}\end{array}$ & $\begin{array}{l}\mathbf{Q} \\
\pm \\
\mathbf{Q}\end{array}$ & $\begin{array}{r} \pm Q \\
q \\
q\end{array}$ & $\begin{array}{l}\mathbf{Q} \\
\underline{q}\end{array}$ & $\frac{\mathrm{Q}}{-}$ \\
\hline Note: & $\begin{array}{l}\text {; redness } \\
\text {; wale ( } \\
\text { oncentratl-si } \\
\text { eans of } \mathrm{Ma}\end{array}$ & & $\begin{array}{l}\text { ing) } \\
\text { ale }\end{array}$ & & & & & & & \\
\hline
\end{tabular}

Exp. 4. Effect of TMA or TMAO Added to Histamine or "Saurine" Observed from the Lethal Dose for Mice $\left(L D_{50}\right)$

Being insensitive or having a high tolerance to biogenic amines, mouse is considered to be unsuitable for the examination for their toxicity. Meanwhile, synergistic action of some biogenic amines to histamine in decreasing its lethal dose for mice was reported by Miyaki et al(1) Therefore, an attempt was made to know the effect of TMA or TMAO added to histamine or "saurine" by testing the lethal dose for mice $\left(\mathrm{LD}_{50}\right)$. 
a. Method The lethal dose of histamine and the effect of the addition of TMA or TMAO upon it were examined by intraperitonial injection into mice. Several groups, each consisted of six mice weighing $16 \pm 2 \mathrm{~g}$, were injected with one test solution. At first, the lethal dose $\left(\mathrm{LD}_{50}\right)$ of histamine-2 $\mathrm{HCl}$ (Merck) was determined by means of Van der Werden's method, and subsequently, the lethal dose of histamine containing $0.5 \times 10^{-4} \mathrm{M}$ each of TMA or TMAO was estimated.

b. Results The $\mathrm{LD}_{50}$ of' each test solution is as follows:

$\begin{array}{ll}\text { Histamine } & 31.9 \pm 1.01 \mathrm{mg} / \text { mouse (Van der Werden) } \\ \text { Histamine+TMA } & 35 \mathrm{mg} / \mathrm{mouse} \mathrm{(Behrens-Kaerber)} \\ \text { Histamine+TMAO } & 36.5 \pm 1.03 \mathrm{mg} / \text { mouse (Van der Werden) }\end{array}$

From the results tabulated in the above, it is obvious that the addition of TMA or TMAO to histamine caused no significant change in the lethal dose of histamine.

\section{Discussion}

Miyaki et al ${ }^{(1)}$ presumed that the causative agents of some outbreak of allergy-like food poisoning should be attributable to the presence of unusual amount of histamine and some synergistic factors such as other kind of putrefactive amines which cooperate with histamine in the responsible foodstuff. Susequently, they stated that TMA, TMAO, phosphorylcholine, agmatine etc. are such substances. In the first place, the authors attempted to learn the effect of TMA or TMAO added to "saurine" or histamine (as control) upon its own physiological action, but failed to show synergism between them.

Using uterus of guinea pigs, sometimes synergistic action of TMA or TMAO added to either histamine of "saurine" was observed to certain extent, and sometimes no action was recorded in the same experiment. Moreover, sometimes strong spontaneous contraction occurred during experiment. These irregular results might have been due mainly to the nature of uterus. However, even when positive synergism occurred, the rate of increase in the action of histamine or "saurine" is small. On the contrary, no synergistic action was observed in the experiment using intestine of guinea pig. Moreover, the addition of TMA or TMAO resulted in no observable change in the action of histamine of "saurine" as tested on shock symptoms in guinea pigs, skin reaction in rabbits and the lethal dose for mice $\left(\mathrm{LD}_{50}\right)$. Therefore, the presence of TMA or TMAO, if any, could not be regarded to stand as a cooperative factor to either histamine or "saurine" in a food responsible for allergy-like food poisoning. Of course, our experiment was restricted in the addition of TMA or TMAO, consequently, the invalidity of TMA or TMAO as a cooperative factor to histamine or "saurine" does not mean the denial of synergism of the whole putrefactive amines. Therefore, the authors wish to extend our experiment to other kinds of amine in future.

Generally, the content of TMAO in fish muscle is considered $(4,5)$ to be rich in white muscle of such species as cod, haddock, seabream (Pagrus cardinalis) 
and so forth, especially, remarkable amount of TMAO is contained in the muscle of elasmobranks, on the other hand, poor in such fishes having reddish muscle. In these muscle, however, a large amount of histidine ${ }^{(6)}$ in free state is contained as compared with that in white muscle, from which such harmful biogenic amine as histamine may be produced by bacteria during the course of putrefaction. The outbreaks of allergy-like food poisoning have been restricted to the consumption of fishes with reddish muscle, so far, therefore, the amount of TMAO contained in the food may not be playing an important role in the outbreak of such poisoning.

As for the amount of TMA contained in the responsible food of outbreaks, the authors' analytical data revealed that about $10-13 \mathrm{mg} \%$ of TMA-N was estimated and trace or slight amount of TMAO was detected in each incriminated food. These findings may suggest that TMAO contained in fish flesh has already been reduced to TMA by bacterial action and the presence of TMAO in such slight amount might not play an important role in the outbreak of allergylike food poisoning when observed from the actual view points, even though a strong synergistic action to histamine it may have.

\section{SUMMARY AND CONCLUSION}

The effect of trimethylamine (TMA) or trimethylamine oxide (TMAO) added to histamine or "saurine" (an autonomic nervous poison like histamine recently isolated by the authors) was examined by means of Magnus' method using intestine or uterus of guinea pigs and, further, by shock symptoms in guinea pigs, skin reaction in rabbits and the lethal dose for mice $\left(\mathrm{LD}_{50}\right)$.

Results obtained are as follows:

1. Using uterus, sometimes synergistic action of TMA or TMAO to either histamine or "saurine" was observed to certain extent, and sometimes no action was recorded in the same experiment. These irregular results might have been due mainly to the nature of uterus. However, even when positive synergism was observed, the rate of increase in the action of histamine or "saurine" was less than $10 \%$.

2. In no case, synergistic action was observed in the experiment using intestine. Results obtained are summarized as follows:

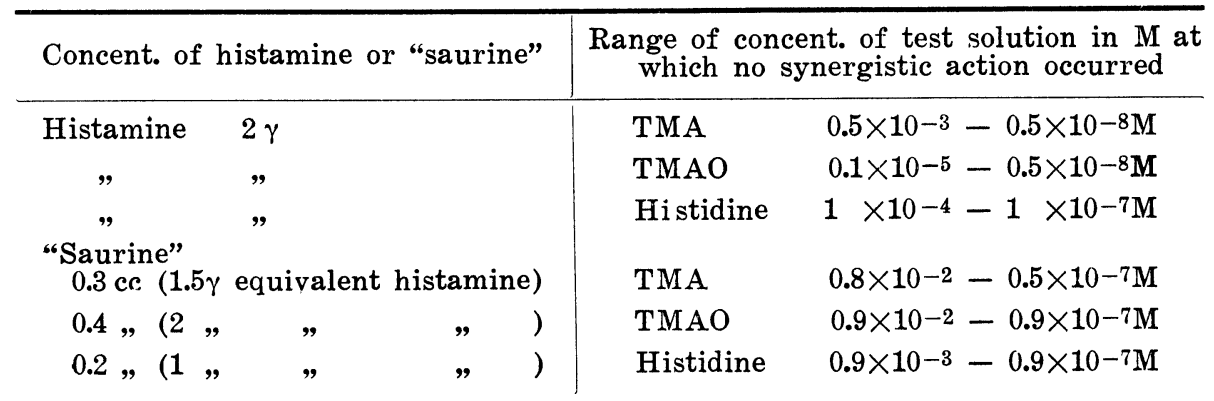


3. The addition of TMA or TMAO to histamine or "saurine" resulted in no appreciable change in the action tested by shock symptoms in guinea pigs, skin reaction in rabbits and the lethal dose for mice $\left(L D_{50}\right)$.

4. Therefore, the presence of TMA or TMAO, if any, could not be regarded to stand as a cooperative factor to either histamine or "saurine" in a foodstuff responsible for allergy-like food poisoning.

\section{ACKNOWLEDGEMENT}

The authors wish to express their thanks to Dr. Y. Tohyama, Chief of the Department of Food Control and Dr. K. Nakamura, Chief of the Department of Serology of the National Institute of Health for their kind guidance and their interest shown in this study, and to acknowledge the suggestion and encouragement given them by Dr. K. Amano of the Tokai Regional Fisheries Research Laboratory throughout this study. The authors also wish to thank the Food Sanitation Section, Public Health Bureau, the Ministry of Health and Welfare for furnishing the required samples of incriminated foodstuffs.

\section{REFERENCES}

1. Miyaki, K. and Hayashi, M.: Investigation of food poisoning caused by ordinary putrefaction. III. Detection of histamine and its synergistic factor in poisoned "samma sakuraboshi" (1). J. Pharm. Soc. Jap., 74, 1145, 1954 (in Japanese).

2. Hayashi, M.: Investigation of food poisoning caused by ordinary putrefaction. IV. Synergism between histamine and several biogenic amines. J. Pharm. Sco. Jap., 74, 1148, 1954 (in Japanese).

3. Kawabata, T., Ishizaka, K. and Miura, T.: Studies on the allergy-like food poisoning caused by "samma sakuraboshi" and other kind of marine products. Jap. J. Med. Sci. Biol., 8, 487, 1955.

4. Norris, E.R. and Benoit, G.J.: Studies on trimethylamine oxide I. Occurrence of trimethylamine oxide in marine organisms. J. Biol. Chem., 158, 433, 1954.

5. Dyer, W.J.: Amines in fish muscle VI. Trimethylamine oxide content of fish and marine invertebrates. J. Fish. Res. Bd. Can., 8, 314, 1952.

6. Shimizu, W., Higashi, Y. and Ishikawa, T.: Studies on muscle of aquatic animals XV. Rept. Res. Inst. Food Sci. Kyoto Univ., 10, 78, 1952. 